\title{
Phytotherapy (Garlic-Allium sativum) in Endometritis Affected Buffalo
}

\author{
S. Alagar*, M. Selvaraju and R. Ezakial Napolean \\ Department of Veterinary Gynaecology and Obstetrics, Veterinary College and Research \\ institute, Namakkal - 2, Tamil Nadu, India \\ *Corresponding author
}

\section{A B S T R A C T}

\section{Keywords}

Baffaloes, Garlic, endometritis and Histology

Article Info

Accepted:

07 February 2018

Available Online:

10 March 2018
In the present study, twelve endometritis affected buffaloes were selected after thorough rectal examination and in absence of palpable uterine abnormalities. Selected animals divided into two group I (treatment group) and II (control group). group I (treatment group, $n=6$ ) were treated with three doses of $10 \mathrm{ml}$ of garlic extract diluted with $90 \mathrm{ml}$ of normal saline three dose at 12 hours interval and group II (Control group, $n=6$ ), were given $100 \mathrm{ml}$ of normal saline intrauterine thrice at the interval of 12 hours. Recovery rate (66.67 and 0 per cent) was higher in treatment group than control group respectively.

\section{Introduction}

Endometritis is one of the most common reproductive disorders of buffaloes and cows. This problem not only affects milk yield but also decreases reproductive efficiency. The annual incidences of uterine infections in postpartum cows range from 10 to $50 \%$ in dairy cattle (Lewis, 1997) and 20 to $75 \%$ in buffaloes (Usmani et al., 2001).

Metritis and endometritis are most common problem in buffaloes affecting fertility and productivity. Various antibiotics and antiseptics have been used intrauterine for the treatment of endometritis. The efficacy of antibiotics needs to be evaluated from time to time since new resistant strains of bacteria can develop due to in-discriminate use of antibiotics (Vekateswaran and Rajeswar, 1991).

One of the active principles of freshly cut garlic homogenates is allicin, which has a variety of antimicrobial activities, and the antibiotic activity of $1 \mathrm{mg}$ of allicin is equated to that of 15 IU of penicillin (Sadanandan et al., 2014). Use of herbal medicine is becoming popular due to toxicity and side effects of allopathic medicine; hence, clinicians felt an urgent need to find out an alternative therapy for the treatment of uterine infections using immunomodulators and phytotherapeutic measures as a means of activation of natural defense mechanism in the uterus (Mandhwani et al., 2017). 


\section{Materials and Methods}

Buffaloes brought to the teaching veterinary clinical complex (TVCC), Namakkal for the treatment of endometritis were utilized for this study $(\mathrm{n}=12)$. Selected animals were divided into two groups via group I (treatment group, $\mathrm{n}=6$ ) were treated with three doses of $10 \mathrm{ml}$ of garlic extract diluted with $90 \mathrm{ml}$ of normal saline at 12 hours interval and group II (Control group, $\mathrm{n}=6$ ), were given $100 \mathrm{ml}$ of normal saline intrauterine thrice at the interval of 12 hours. At subsequent estrus the treated buffaloes were subjected to artificial inseminated, and those buffaloes which returned to heat after first AI were again inseminated during the subsequent estrus.

\section{Histopathology}

After recording the gross lesions the uterine tissue was collected from slaughtered buffaloes and subsequently preserved in 10\% neutral buffered formalin for $48 \mathrm{~h}$.

Further these tissues were processed by routine method of dehydration in graded acetone, clearing in benzene and embedding in paraffin. Sections of 4 to 5 micron thickness were processed by standard procedures using routine Haematoxyline and Eosin, VerhoeffVan Gieson stain for collagen (Sharma et al., 2004) for histopathological studies. Tissue samples were collected before and after the treatment in all the animals.

\section{Results and Discussion}

Before treatment in most of the cases endometrium showed loss of surface epithelium with infiltration of lymphocyte, degenerative and necrotic changes (Fig. 1). Desquamation of lining epithelial cell was prominent. Further, sub-epithelial hemorrhage and hyperactivity of endometrial glands were also noticed. In a few cases, complete desquamation of lining cells with serous edema, marked infiltration of mononuclear cells in sub-epithelial area were noticed. Atropic changes in endometrial glands were evident (Fig. 2).

After treatment regeneration of lining epithelium of endometrium with scattered mononuclear cell infiltration in sub-epithelial area was noticed. Endometrial tissue revealing regeneration $\mathrm{o}$ surface epithelium and infiltration of macrophages in the submucosa were evident. The submucosal gland showed regeneration and hyperplasia of the glandular cells and fully grown surface epithelium appeared almost normal (Fig. 4). On contrary, the control group revealed no such change but loss of endometrial epithelium, lymphocytic infiltration in the uterine glands and excessive inter glandular collagen deposit (Fig. 2).

Table.1 Effect intrauterine infusion of garlic extract on recovery (per cent) in buffaloes with endometritis

\begin{tabular}{|c|l|c|c|}
\hline $\begin{array}{l}\text { S. } \\
\text { No }\end{array}$ & $\begin{array}{l}\text { Treatment } \\
\text { groups }\end{array}$ & $\begin{array}{l}\text { No of } \\
\text { animals } \\
\text { recovered }\end{array}$ & $\begin{array}{l}\text { Recovery } \\
\text { rate }\end{array}$ \\
\hline 1 & G I (Garlic extract) & 4 & 66.67 \\
\hline 2 & Control (Control) & 0 & 0 \\
\hline
\end{tabular}




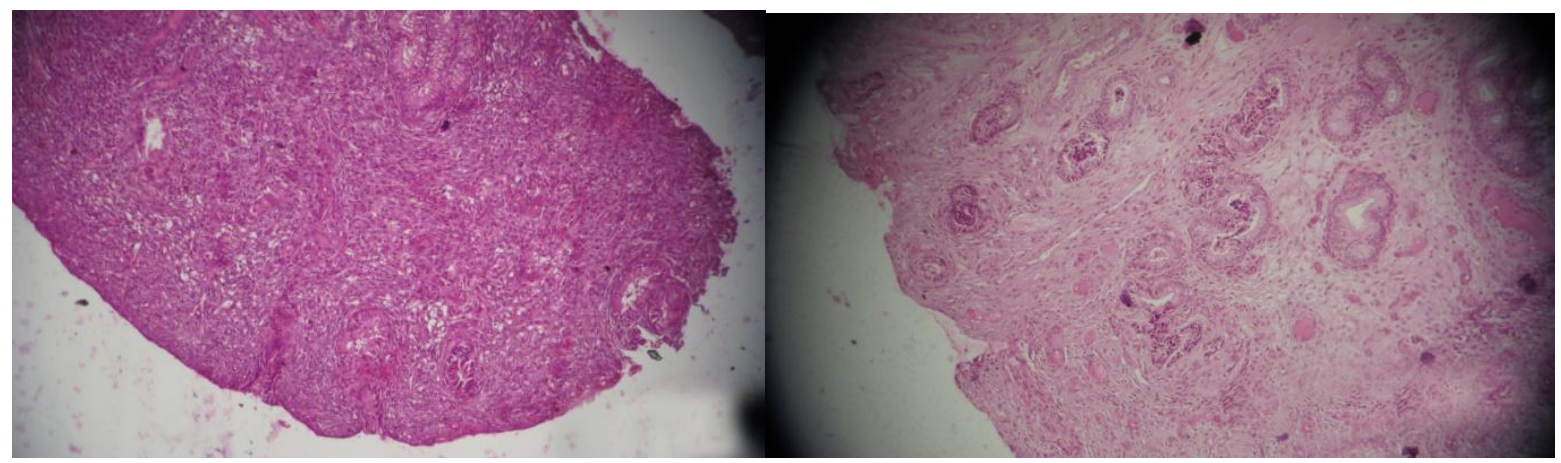

Fig.1 Before treatment (Control)

Endometrium showing surface and glandular epithelial damage and lymphocytic infiltration

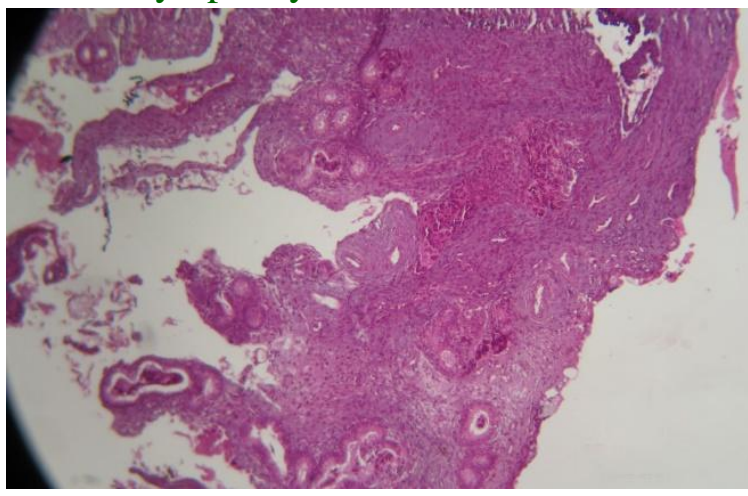

Fig.3 Before treatment (Treatment)

Loss of endometrial epithelium, lymphocytic

infiltration in the uterine glands and hyperactivity in concentration of uterine glands

In group I 66.67 per cent buffaloes were recovered and 50.00 per cent conception rate was obtained after treatment with garlic extract (Table 1).

Whereas none of the buffaloes were recovered after treatment in control group.

Similar to the study of Kumar et al., (2013) who reported 75 per cent recovery rate and 66.7 per cent conception rate in buffaloes treated with garlic extract in an another study, kumar et al., (2009) reported 80 per cent recovery rate and 75 per cent became pregnancy rate in buffaloes affected with endometritis. From the study, it is concluded that garlic extract can be effectively used for
Fig.2 After treatment (Control)

Loss of endometrial epithelium, lymphocyte infiltration in the uterine glands and excessive inter glandular collagen deposits.

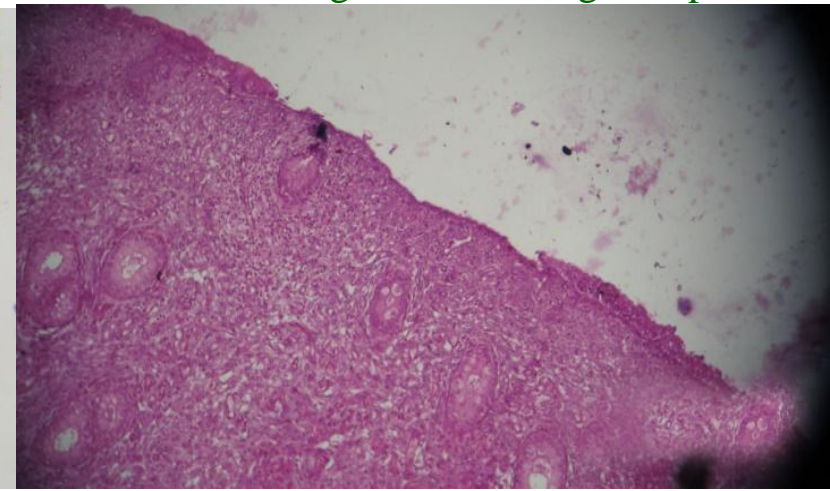

Fig.4 After treatment (Treatment)

Regeneration of endometrial epithelium, increased number of uterine glands and absence of inter glandular collagen deposits

treatment of endometritis in buffaloes. However, experiment with more number of animals may further confirm its efficacy.

\section{References}

Kumar, H., N. Shooshan, P. Barman and M.C. Yadav. 2009. Administration of herbal antimicrobials recovers the endometritis in buffaloes. Indian J. Anim. Sci., 79:679-690.

Kumar, H., N. Shooshan, R.S. Das and A. D. Garg. 2013. Effect of treatment of immunomodulation on recovery and conception rate in endometritic buffaloes. India J. Anim. Sci., 83: 129132. 
Lewis, G. S. 1997. Health problems of the postpartum cow, uterine health and disorders. J. Dairy Sci., 80: 984-994.

Mandhwani, R., A. Bhardwaz, S. Kumar, M. Shivhare and R. Aich. 2017. Insights into bovine endometritis with special reference to phytotherapy. Veterinary World, EISSN: 2231-0916.

Sadanandan, B., L. Prerna, H. Humtsoe and A. Mishra, 2014.Antibacterial activity of garlic against bacillus subtilis. Int. Rev. Appl. Biotechnol. Biochem., 2: 107-119.

Sharma, I. J. 2004. Physiological Basis of Veterinary Practice, 1st ed. Publishing
Co., Kalyani Publishers, New Delhi, India. p. 267-268.

Usmani. R. H., N. Ahmad, P. Shafiq and M. A. Mirza. 2001. Effect of subclinical uterine infection on cervical and uterine involution, estrous activity and fertility in postpartum buffaloes Theriogenology, 55: 563-571.

Vekateswaran, K.V. and J. J. Rajeswar. 1991. Antibiotic sensitivity pattern of microorganisms causing infertility among cattle in Kanyakumari District of Tamil Nadu. Indian Vet. J., 68(2):187188.

\section{How to cite this article:}

Alagar, S., M. Selvaraju and Ezakial Napolean, R. 2018. Phytotherapy (Garlic-Allium sativum) in Endometritis Affected Buffalo. Int.J.Curr.Microbiol.App.Sci. 7(03): 762-765. doi: https://doi.org/10.20546/ijcmas.2018.703.089 